\title{
The Political Economy of Industrial Relations, Labour Productivity and National Development in Nigeria, 1990-2014*
}

\author{
Emmanuel Nwafor Mordi, $\mathrm{PhD}^{*}$ \\ Department of History \& International Studies, Delta State University, Abraka, Nigeria \\ *Email: emmanumordi@yahoo.com Phone No: 08036761418
}

\begin{abstract}
The nexus between industrial relations, labour productivity and national development in Nigeria, 1990-2014, was studied from a political economy perspective, against the background of the expectations of the political class that a labour force that is exposed to the insecurity and massive corruption of the Nigerian state can drive national development through enhanced labour productivity. Adopting the analytic- critical method of contemporary history, this study interrogated Nigeria's political and economic fact sheet since 1990. It concluded that without an enabling environment, including the necessary security architecture, labour productivity and national development could not flourish, and the government which failed in its duty to bring this about, should shoulder the responsibility of reversing the trend.
\end{abstract}

Keywords: National Development, Labour Productivity, Political Economy, Post-Independence Nigeria

\section{Introduction}

In spite of the vast wealth accruing to Nigeria from her huge oil resources, she has continued to present the paradox of poverty in the midst of plenty. Nigeria consistently ranks very low on the development scale, such that some non-oil producing African countries often record greater per capita income than her. The same trend is noticeable in other indices by which countries are ranked as developed, developing or under developed, including security, employment, corruption, quality of life of the citizenry, ability to control and direct the process of growth to serve local needs, as well as high labour productivity. Thus, Akani (2007) observes the general trend whereby "oil windfalls that should have ushered in sustained economic growth have exacerbated slow growth and engendered poverty" (12). It would appear that by 2014, the Nigerian government had concluded that Nigeria's inability to rise up to the expectations imposed on her by her vast size as Africa' s most populous country of about 170 million people, with abundant natural resources should be attributed to low labour productivity. Perhaps, to underscore the critical role of labour productivity in national development, and a new official initiative in that direction, the theme of the 2014 local study tour organized for participants in the senior executive course SEC No. 36 of Nigeria's National Institute for Policy and Strategic Studies (NIPSS), Kuru, was "Industrial Relations, Labour Productivity and National Development" (Folarin 2014: 1; Fashola 2014).

The critical role of labour productivity in national development is well known. However, Nigeria's persistently very low labour productivity, which, by 2008 ranked below the average for the rest of Sub-Saharan Africa (Umoru \& Yaqub 2013: 199-200) would seem to have attracted new official attention in the aftermath of Nigeria's rebasing of her Gross Domestic Product, with 2010 as the base year. The rebasing of the GDP for the first time since 1990, almost a quarter of a century, catapulted Nigeria to Africa's first and biggest, overtaking South Africa, as well as the world's 26th ranking economy (Kale 2014; Nwakilishi 2014). The mixture of euphoria and cynicism which greeted the rebasing meant that government must take every necessary step to sustain Nigeria's new economic status. Given her poor record of industrial relations since the end of the Nigerian civil war, as shown in frequent industrial actions by notably government employees (Awe and Ayen 2010:336), there seems to be the erroneous belief that the way forward is to weaken the collective bargaining power of labour through decentralization, and thereby enhance labour productivity and national development (Okedinachi 2014; labour unions).

By implication, the new ranking suggests that since 1990, Nigeria has improved tremendously the quality of life of her citizens, and of governance, which was waiting to be confirmed by the GDP rebasing. Yet, the period, 1990-2014 was characterized by fundamental economic and political developments which were accompanied by 
social convulsions in Nigerian history. It coincided with a period of prolonged, brutal military dictatorship, characterized by disingenuous, aborted transition to civil rule programmes, aptly described as "transition without end" (Diamond, Kirk-Greene and Oyediran 1997: xv-Xvi), and an eventual smooth return of democratic governance in 1999, which was closely followed in 2007 and 2011 by civilian-civilian change of leadership batons. The period also coincided with the end of the decade, 1980-1990, of the United Nations Programme of Action for Africa's Economic Recovery and Development (UN-PAAERD), which was characterized by the failure of the neo-liberal formula of privatization, trade liberalization, withdrawal of subsidies, and policy shift against government intervention in the local economy, with concomitant mass immiseration. The latter gave way to the Millennium Development Goals (MDGs), which was expected to combat problems of poverty, disease, hunger, environmental degradation and discrimination against women (Mordi 2009).

Yet, the stark reality is that Nigeria remains in the backwaters of national development, with extreme poverty, burgeoning unemployment, and almost crippling insecurity which seems to overwhelm national security architecture and expose the state machinery of governance to national and international opprobrium. The beaming of government searchlight on industrial relations and labour productivity vis-à-vis the problems besetting national development in Nigeria seems to be government's own way of throwing the stone back at the labour force and absolving itself from blame for Nigeria's development quagmire.

Against this backdrop, it is the objective of this paper, using the political economy approach to interrogate the Nigerian state with the fact sheets on the Nigerian economy and politics vis-à-vis the character of industrial relations and contributions of labour productivity to the unimpressive level of Nigeria's development. Given the huge endowments of Nigeria and the report card of her various attempts at state-driven development since independence, would the analytic-critical method of contemporary historical enquiry uphold government's continued beaming of its searchlight on the labour force in the quest for explanations for Nigeria's failure to deliver? What does the evidence suggest, and where should the searchlight be beamed as we seek for viable solutions to Nigeria's development quagmire?

\section{Political Economy as a Tool of Analysis}

Caporaso and Levine (2005) note that political economy as a method of analysis has adopted changing frameworks within which scholars have sought to understand the relation between politics and economics. They range from the classical, Marxian, Keynesian, neoclassical, state-centred, power-centred, to justice-centred. At the core of the debate is the responsibility of the state in economic matters. Should the responsibility to provide and, indeed satisfy, and determine which wants of the citizens to satisfy and the mobilization of resources to that end be shouldered by the state, or left with the individual as private agents, driven by private calculations? In other words, should the state politically intervene in the economy to serve public goals, or respond to private interests? The classical approach which emphasizes a laissez faire approach built on the capacity of markets to regulate themselves is no longer fashionable, as social scientists agree that the economy is necessarily political. They tend to be guided by the theories of Karl Marx. Contemporary approaches, however, identify politics with the use of power, which at any rate resides in the economy, and therefore view political economy in the context of the political nature of the economy, whether or not it is regulated by government. The state -centred approach divests the state of all encumbrances while allowing it to pursue its agenda, provided that the state can control the economy to impose its political agenda.This brings in the issue of justice in that the political process can alter property rights, and therefore redefine the limits of the market. These contending perspectives have remained unresolved, while political economy has not succeeded in integrating politics into economics. The Marxian approach encompasses the divergent strands, and is best suited to the Nigerian state, which since independence has been running to and fro between state-driven development and regulated private sector involvement.

As enunciated by Marx, the political economy approach emphasizes holistic enquiry, and indeed an in-depth comprehensive appreciation and understanding of social reality. It is based on 'the materialist conception of history', otherwise known as 'historical materialism', two labels invented by Karl Marx's (1818-1883) collaborator Fredrick Engels (1820-1895). Implicit in the materialist conception of history, described by latest Marxists as the 'economic interpretation of history' and 'dialectical materialism' as formulated by Marx in 1859 , is that the general character of any society is determined by its economic structure. The latter, the 'base' describes the manner in which goods are produced, the foundation upon which is built the dominant ideologies, political and legal institutions of society. This process inevitably breeds conflict because "At a certain stage of their development, the material productive forces of society come into conflict with the existing relations of production within which they have been at work hitherto" in such a way that "these relations turn into their fetters" and trigger a transformation of "the entire immense superstructure". As a consequence, "men become 
conscious of this conflict and fight it out" (Marx cited in Law 1978: 42).

The class conflict involves the owners of the means of production, i.e. the bourgeoisie, and the workers, or proletariat who have only their labour to offer in exchange for a wage, even as the bourgeoisie driven predominantly by the profit motive decide what to do with the product of labour. The instrument of coercion and the legal system are put in the service of the state to ensure that the relationship which guarantees the profit of the bourgeoisie and that the workers continue to be exploited is not threatened. Thus, this capitalist arrangement of the exploiter and the exploited is the real foundation upon which the superstructure of social, political, and intellectual consciousness is built (Wallerstein cited in Imhonopi and Urim 2012).

Implicit in the economic interpretation of history then is that the general character of any society is determined by its "economic structure", namely by the manner in which goods are produced, which can only be fully grasped in its total historical context of the 'dialectical' relationship involving all spheres of society (Mojuetan 1990). This general character of society is what the Marxist schema sets out to explain in economic terms. Even so, Marx and Engels were not oblivious of the fact that in some "specific historical contexts" their schema was reversed, such that "economic growth might be promoted or obstructed by political action or by the prevalence of particular ideas or values (Law 1978: 45-46). The political economy approach therefore merely describes a particular approach to the explanation of historical phenomena, as we have set out to do on the Nigerian development record.

\section{Political Economy Perspectives of Industrial Relations, Labour Productivity and National Development}

In simple terms, political economy analyzes the way the economy of a country is controlled, and the relationship between it and the state as distinct from the government. This boils down to the issue of class and roles of classes in the production process. The foundation, land, tools, materials or the means of production is controlled by a powerful group of rich people, who deploy their wealth to acquire power, and institute laws and other superstructure to defend the status quo. Their objective is to maximize profit by exploiting the other classes, usually workers, peasants, and the dispossessed category. The worker has no power of his own to decide how what he produces is utilized, distributed, or the means of exchange since he is paid a wage for his labour. Class consciousness and antagonism consequently grow (Fashina 2014).

In this environment of the workplace, characterized by conflicting interests and class antagonism, some form of order governed by rules and regulations, some contractual agreement, become imperative to guide the relationship between the employee or worker and the owner of the means of production who has invested his wealth with the profit motive. Industrial relations can therefore be viewed from the perspective of the network of rules, which governs the workplace and the work community, the character of the rules and the manner in which they are formulated, administered and altered. Thus, the employer, the employee represented by his workers' organization and the government as an "employer of labour and custodian of public good" are involved in this relationship, which is underpinned by production relations. They all are committed to the "continued existence of the workplace" (Adewunmi 2014: 32). By implication, the three stakeholders in industrial relations are committed to labour productivity which has a direct effect on the purchasing power of workers. When workers embark on work stoppages, work to rule and other forms of industrial action, labour productivity is adversely affected as many man-days are lost (Awe and Ayeni 2010), as has characterized industrial relations in Nigeria since the end of the civil war.

\section{The Nigerian Paradox}

Viewed from a political economy perspective, the Nigerian State since independence is an embarrassing paradox. Nigeria is naturally blessed with important resources as uranium ore, iron ore, limestone, lead and petroleum among others. Petroleum is the main foreign exchange earner for Nigeria. Since taking up her membership of the Organization of Petroleum Exporting Countries (OPEC) in 1971, and in the aftermath of the Arab-Israeli war of 1973, Nigeria has remained an oil-dependent neo-colonial economy. Such is the dependence on oil that the oil and gas sector between 2011 and 2012 accounted for over 95\% of Nigeria's total earnings from export, and not less than $85 \%$ of total government revenue. Nigeria's dependence on the export of crude oil and natural gas is such that her economy is characterized as monoculture with an additional negative feature among OPEC member states of a country where crude petroleum products rank as the highest single contributor to country export (Udosen, Ekot and George 2009:37-38; Aluko 2005. Html; African Economic Outlook: 2; Chete, Adeoti, Adeyinka and Ogundele 2014: 1-2). Indeed it is estimated that between 2000 and 2009, total oil revenue accruing into the Federation Account 
amounted to \#34.2 trillion, giving a ratio of $82.36 \%$ of oil revenue to $17.64 \%$ of non-oil revenue (Ogbonna and Ebimobowei 2012: 33-34). The trend did not abate by 2012, when the value of Nigeria's total export amounted to $\$ 142.52$ billion, out of which petroleum exports accounted for $\$ 94.54$ billion, representing $66.33 \%$ (OPEC 2013).

The huge revenue from oil was either pilfered, or squandered by state officials, and not spent on the welfare of the citizenry. This is reflected in Nigeria's Low Human Development Index ranking among members of the Organization of Petroleum Exporting Countries (OPEC), placing her at the bottom with Angola out of the 12 countries ranked(Wikipedia). The literature indeed shows that huge wealth from oil, especially under autocratic regimes was often an instrument to keep the government in power and, therefore, tended to oil the wheel of corruption. Even in democratic settings, the evidence suggests that in the oil exporting countries, oil does a greater damage to democracy. The phenomenon has been described as resource curse, especially in an environment "where rent-seeking and production are complementary competing activities" (Akanni 2007:4).

For instance, Nigeria's military head of state had declared in 1973, during a state visit to the Caribbean that Nigeria's problem was not money but how to spend it. Subsequently, after the fall of the Gowon regime in 1975, a commission of enquiry absolved only two of the twelve military governors from blame of corrupt enrichment. Before its collapse, the regime approved the supply of 20 million tons of imported cement, 16 million of which was for the Ministry of Defence, even though Nigerian ports had handling capacity for only one-tenth of the number. As a result, over 450 ships laden with cement, could not berth at Nigerian ports, and the government had to pay over 500,000 dollars daily in demurrage charges (Dudley 1982).General Babangida followed in Gowon's footsteps. During the Gulf War of 1991, Nigeria reaped about \$12.3 billion dollars which in spite of a government panel-the Pius Okigbo report of 1994-could not be accounted for (Aluko 2005). Besides, even though between 1999 and 2003, the Nigerian government announced that it had spent N300 billion on road construction, the evident collapse of Nigerian roads could not justify that claim, nor could the several billions of dollars squandered on energy be reflected in improved electric power generation and distribution to Nigerians (Udosen et al 2009), recent privatization of the energy sector, notwithstanding.

Not surprisingly, Nigeria virtually occupied the bottom rung in the whole wide world in the Corruption Perception Index by 2005. In the index ranging between 10 (highly clean) and 0 (highly corrupt), Nigeria scored 1.9 and occupied the 154th position out of 158 countries, below Cote d'Ivoire and Equatorial Guinea and beating only Chad of the 41 African countries listed. Thus, such collapsed states as Somalia and Congo DR, Libya and Mali were perceived as less corrupt by business people, academics and risk analyst. In 2013 Nigeria marginally moved up to 144th position in Transparency International Corruption Perceptions Index (Transparency International 2006, 2014).

Indeed corruption and lack of accountability have characterized Nigerian political leadership since independence (Ogbeide 2012), even as various Nigerian governments took some measures at least, on paper to address it. For instance, President Obasanjo continued with the anti-corruption crusade, and, in 2003, established the Economic and Financial Crimes Commission (EFCC). The latter was an inter-agency, which was a body saddled with the responsibility to investigate, prosecute, and penalize persons suspected of engaging in such economic and financial crimes as "money laundering, embezzlement, bribery, looting and any form of child labour, illegal oil bunkering", advance fee fraud and other related offences. The commission did function to reduce incidences of corrupt practices in Nigeria, but there was a public perception that the EFCC was not independent, as it "was used by the government to deal with perceived opponents and enemies" (Ngwube and Okoli 2013: 101-104).

The Nigerian pattern in the fight against corruption thus falls into the pattern observed elsewhere in Africa, where it has been noted that:

frequently, official drives against corruption were short-lived, forgotten once the initial zeal for reform had faded or the new authorities themselves succumbed to temptation. They were also often highly selective, designed in part to deny rival factions the financial resources necessary to mount effective political challenges, while maintaining a monopoly on illicit accumulation for those currently in authority and/or favour (Harsch 1993:33).

Indeed corruption, which encompasses outright theft or embezzlement of public funds, acts of nepotism driven by unlawful wielding of influence or desire to accumulate resources or gain in enhanced status, cuts across 
different segments of society. It assumes diverse dimensions, the most dangerous of which involves the state's use of corruption as an instrument of political power and domination, dispensing jobs and other resources to supporters in a patron-client relationship. In this case, the political class, without investment in the production process, without a strong economic base, and without any interest whatsoever in industrialization is obsessed with the primitive accumulation of resources for the control of state power, which it in turn utilizes to entrench its class domination. Indeed it is through corruption, instead of production, that former and serving officeholders, directors of public enterprises, as well as party leaders illegally amass wealth while posing as entrepreneurs. In effect, corruption oils the formation, entrenchment and consolidation of the political class into the bourgeoisie. So much is the process dependent on state resources that loss of access to state power, or patronage, or even "loss in presidential favour or downfall of a political patron can mean an abrupt end to one's business prospects" (Harsch 1993: 37-39).

This is particularly true of a neo-colonial economy like Nigeria, where the government remains the largest employer of labour, and privatization without government patronage is a mere paper tiger. Given the character of Nigerian politics and of a very weak private sector, which is hugely dependent on government patronage for its sustenance, economic success is primarily a function of state patronage. Thus the elite outside the ruling party, what Ake (1996) calls "the hegemonic faction of the political elite" could only dream of getting wealthy by engaging in entrepreneurial activity at their own peril. In any case, it is not necessary to do so because political power was everything; providing not only access to wealth but also the sole guarantor of personal, as well as group security and general wellbeing. In fact, members of the ruling faction of the political class could "appropriate surplus with less risk and less trouble by means of state power" (7). As a consequence, "much of what passes for 'manufacturing' amounts to little more than the processing and repackaging of imported components, with not much evidence of the 'backward linkage',' (Dudley 1982: 238, 242). In the circumstance, privatization programmes were doomed to end in disaster. Thus by 2011 , less than 10 per cent of the 200 privatized government firms were viable, the rest having laid off their workers, and either producing nothing or at best below capacity. The situation could not have been otherwise, given that the privatized enterprises had been underpriced and sold to cronies of those in power (Amali 2011).

The consequences of this state of affairs for labour productivity and national development were dire. For instance, Nigeria was ranked the 13th poorest country in the world by 1993, due to her embarrassing index of human misery. Among the components of the index of human misery are falling real wage, falling standard of health care and education, as well as rising rate of unemployment. Indeed, a steady high incidence of unemployment of $21.1 \%$ in 2010, 23.9\% in 2011 and 25\% in2012, above the sub-region's average, with an increased population of $61.2 \%$ by 2010 living on less than $\$ 1$ per day, and a misery index of $39.9 \%$ combining inflation $(12.0 \%)$ and unemployment $(23.9 \%)$ in 2012 characterized the Nigerian economy.

The magnitude of the danger posed by unemployment comes into bold relief when taken in conjunction with the distribution of the unemployment statistics, which show that $41.6 \%$ of the unemployed by 2011 represented 15 24 year olds, while 45-59 year olds constituted $11.5 \%$, with those above 65 years making up $16.7 \%$. The incidence of unemployment was more among females $(24.9 \%)$ than for males $(17.7 \%)$, just as the North-East and Niger Delta of Nigeria harboured the highest concentration of the unemployed (United States Embassy in Nigeria 2012), with dire consequences for the security of the region and indeed Nigeria as the Niger Delta militancy and the festering Boko Haram insurgency illustrate. The implications of these statistics for the current insecurity situation, and moral laxity in Nigeria are self evident.

Indeed a major constraint to the attainment of enhanced labour productivity and national development was the breakdown of the security architecture of Nigeria, which was a manifestation of the failure of governance. Although threats to national unity predated Nigeria's independence and were backed by force of arms for the first time in the abortive secessionist bid of the Igbo between 1967 and 1970 (Tamuno 1970), yet manifestations of fissiparous tendencies in the form of agitations for confederation by 1986 (Osaghae 2008), did not become any cause for serious national concern until Nigeria's return to civil rule in 1999(Mordi 2004) .Various manifestations of urban violence wreaked by ethnic militias threatened the consolidation of Nigeria's fledgling democracy(Babawale 2003), and by 2004, had assumed such a frightening dimension as to lead Rotberg to categorize Nigeria as a weak state, the country having been upgraded from its 1990's categorization as a collapsed state. Whereas a collapsed state refers to the highest form of state failure which is characterized by the authority vacuum, a weak state is characterized by "internal antagonism", in addition to harbouring "ethnic, religious, linguistic, and other inter-communal tensions that have not yet, or not yet thoroughly become overtly violent". Given the overtly violent eruptions of Boko Haram in the North-East of Nigeria, and the scale of insecurity across the country, including kidnapping of citizens by armed gangs, it is doubtful if Nigeria had not 
become a failed state: "Failed states are tense, deeply conflicted, dangerous, and contested bitterly by warring, factions", with government security forces battling to contain "armed revolts led by one or more rivals". Even more worrisome is that as it is typical of failed states, Nigerian authorities were contending with "two or more insurgencies, varieties of civil unrest, different degrees of communal discontent, and a plethora of dissent directed at the state and at groups within the state"(Rotberg 2004:3-10).

Rotberg wrote before the contemporary terrorism unleashed on parts of Nigeria by the Jama' atul Ah lus Sunna Lid'Da'awatis Jihad, popularly known as Boko Haram which by 2014 had led to loss of thousands of lives and cast much doubt on the capacity of the Nigerian state to discharge its primary obligation of security of life and property to all Nigerians (Hassan 2014; Nwanegbo and Odigbo 2013). The Boko Haram insurgency raged side by side with other manifestations of insecurity, notably armed robbery and kidnapping of defenseless citizens by armed gangs. For instance, between January, 2012 and May, 2013, Nigeria's Delta State Police Command arrested 632 suspected armed robbers/kidnappers, killed 123 kidnappers/armed robbery suspects in action, and rescued 119 kidnapped victims ( Mordi 2014:6)The bottom line is that the high level of insecurity which casts doubt on the capacity of the Nigerian state to fulfill its primary function of guaranteeing human security, a critical index of state failure, cannot make for a conducive work and national environment for increased labour productivity.

Lack of institutional environment, low level of efficient infrastructure which manifests in the absence of constant supply of electricity in spite of the privatization of the energy sector, poor quality of roads and rail road infrastructure, coupled with inadequate health facilities further bedeviled national development driven by labour productivity (World Economic Forum). Other indications include lack of effectiveness and efficiency of government agencies in the discharge of their duties in the regulation and supervision of industrial relations matters (Okaka, and Eriaguna 2011).

This also explains why labour productivity is naturally of interest to a government which provides the bulk of the work force, and regularly contends with workers demonstrations, lock outs, work-to-rule, or mass work stoppage popularly referred to as strike action. Government tends to be unduly interested in only the contribution of the labour factor such that labour productivity focuses on production or real gross domestic product (GDP) per person-hour worked, or production (real GDP) per person employed. Government ought to be interested even more in hours worked per person employed, even so in the number of persons employed relative to the total labour force by taking into consideration the number of the unemployed persons, subject to the 'working age' population and the share of the working age population in the total population. It is thus easy to have an idea of the fraction of the population that is employed vis-à-vis the number that is unemployed. For this reason, "differences among countries in average labour productivity, a measure of economic performance, and income per capital, a measure of living standards, are determined by differences in the number of annual working hours per person and the share of the population that works". We cannot be trumpeting the need for enhanced labour productivity in which we emphasize labour force participation rates without addressing the equally important labour market indicators, such as working hours and unemployment, as well as purchasing power parity (PPP). The latter refers to "the amount of a country's currency that is required to purchase a standard set of goods and services with one unit of the currency of another (base) country" (Ark and McGuckin 1999).

In addition, in terms of Human Development Index, Nigeria fared miserably. This is so in terms of a "comparative measure of life expectancy, literacy, education, and standards of living" worldwide, and therefore, a standard of assessing the wellbeing of the citizenry, measuring 'the impact of economic policies on quality of life', and ranking a country as developed, developing, or underdeveloped (List of African Countries by Human Development Index). Thus, in 2009, Nigeria was ranked 158th out of 182 countries and 29th in HDI among African countries, trailing behind Seychelles, Mauritius and Sudan (Amali 2011:394). On the 2014 list of African Countries by the HDI, Nigeria is placed in the Low Human Development Category, marginally improving from 158 to 153 in world ranking(Wikipedia).In essence, Nigerians were very poor, in fact, pauperized. Over $70 \%$ of Nigerian households lived in poverty, 187 out of 1000 live births died before the age of five years, with illiteracy level at $41 \%$, a low life expectancy of 52 year, and $43 \%$ of the population lived below poverty line. To cap it all, Nigeria by 2001, was lowly ranked in terms of political stability, rule of law, government effectiveness, and anti-corruption (Table 1). 
Table 1: Comparison of Five Basic Development Indices among Ten Selected African Countreis

\begin{tabular}{|l|l|l|l|l|l|l|}
\hline S/N & $\begin{array}{l}\text { COUNTR } \\
\text { Y }\end{array}$ & $\begin{array}{l}\text { GPD per } \\
\text { person, } \\
\text { purchasing } \\
\text { power parity }\end{array}$ & $\begin{array}{l}\text { Government } \\
\text { Effectiveness } \\
{[\%]}\end{array}$ & $\begin{array}{l}\text { Political } \\
\text { Stability [\%] }\end{array}$ & $\begin{array}{l}\text { Anti } \\
\text { Corruption } \\
{[\%]}\end{array}$ & $\begin{array}{l}\text { Rule of Law } \\
{[\%]}\end{array}$ \\
\hline 1 & Nigeria & $\$ 1,500$ & 16.6 & 3.8 & 5.8 & 8.1 \\
\hline 2 & DR Congo & $\$ 700$ & 1.9 & 1 & 2.9 & 1.9 \\
\hline 3 & Liberia & $\$ 900$ & 6.6 & 12.5 & 20.4 & 11 \\
\hline 4 & Kenya & $\$ 1,200$ & 28 & 15.4 & 16 & 15.7 \\
\hline 5 & Mauritius & $\$ 13,700$ & 71.6 & 79.3 & 66.5 & 75.7 \\
\hline 6 & $\begin{array}{l}\text { South } \\
\text { Africa }\end{array}$ & $\$ 13,300$ & 76.8 & 44.2 & 70.9 & 58.6 \\
\hline 7 & Botswana & $\$ 10,900$ & 73.9 & 93.3 & 78.2 & 67.1 \\
\hline 8 & Angola & $\$ 4,500$ & 10.9 & 28.8 & 8.7 & 7.1 \\
\hline 9 & Senegal & $\$ 1,800$ & 47.4 & 37.5 & 41.7 & 45.7 \\
\hline 10 & Rwanda & $\$ 1,600$ & 39.8 & 27.4 & 55.8 & 34.3 \\
\hline & $\begin{array}{l}\text { Sub- } \\
\text { Saharan }\end{array}$ & $\begin{array}{l}\text { Averld } \\
\text { Average }\end{array}$ & 27.2 & 35.6 & 30.3 & 28.8 \\
& $\begin{array}{l}\$ 10,200 \\
\text { Average }\end{array}$ & & & & \\
\hline
\end{tabular}

Source: Charles Udosen et al (2009: 43).

The evidence suggests that the Nigerian worker was grossly under remunerated. He had to embark on a strike action in 2011 for the minimum wage of $\$ 18,500.00$ to be approved for him by the state. More strike actions had to be embarked upon to compel some state governments to pay, even as some refused to pay. Yet it has been suggested that Nigerian legislators, on the other hand, were super abundantly remunerated compared to their counterparts across the globe (Table2).

Table 2: Earnings of Nigerian Legislators Compared to other Countries

\begin{tabular}{|c|c|c|c|c|c|}
\hline Country & $\begin{array}{l}\text { Legislators pay } \\
\text { monthly }\end{array}$ & $\begin{array}{l}\text { Legislators pay } \\
\text { annually }\end{array}$ & $\begin{array}{l}\text { Minimum wage } \\
\text { monthly }\end{array}$ & $\begin{array}{l}\text { Minimum wage } \\
\text { annually }\end{array}$ & $\begin{array}{l}\% \text { of } \\
\text { Legislators } \\
\text { pay that is } \\
\text { minimum } \\
\text { wage }\end{array}$ \\
\hline Nigeria & $\begin{array}{l}\text { Senate: } 15.2 \mathrm{~m} \\
\text { Reps: } 10.6 \mathrm{~m} \\
(\$ 69,533\end{array}$ & $\begin{array}{lr}\text { Senate: } & \$ 182 \mathrm{~m} \\
\text { Reps: } & \\
(\$ 834,402 & \end{array}$ & $\begin{array}{l}\$ 18,000 \\
(\$ 118.15)\end{array}$ & $\begin{array}{l}\$ 234,000 \\
(\$ 1,536) \\
\text { Inclusive of } 13^{\text {th }} \\
\text { month salary }\end{array}$ & $\begin{array}{l}0.13 \% \\
0.18 \%\end{array}$ \\
\hline India & $\begin{array}{l}\$ 305,058 \\
(\$ 1,999)\end{array}$ & $\begin{array}{l}\begin{array}{l}N 3.7 \mathrm{~m} \\
(\$ 23,998)\end{array}\end{array}$ & $\begin{array}{l}\text { Varies from state } \\
\text { to state; sector to } \\
\text { sector }\end{array}$ & - & - \\
\hline US & $\begin{array}{l}\$ 2.2 \mathrm{~m} \\
\$(14,500)\end{array}$ & $\begin{array}{l}\$ 26.5 \mathrm{~m} \\
(\$ 174,000)\end{array}$ & $\begin{array}{l}\$ 191,667 \\
(\$ 1,257)\end{array}$ & $\begin{array}{l} \\
\approx 2.3 \mathrm{~m} \\
(15,080)\end{array}$ & $8.6 \%$ \\
\hline UK & $\begin{array}{l}\text { ( } 1.3 \mathrm{~m} \\
(\$ 8,686)\end{array}$ & $\begin{array}{l}15.9 \mathrm{~m} \\
(\$ 104,228)\end{array}$ & $\begin{array}{l}\$ 283,333 \\
(\$ 1,883)\end{array}$ & 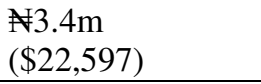 & $21.68 \%$ \\
\hline Sweden & $\begin{array}{l}\mathrm{N} 1.02 \mathrm{~m} \\
(\$ 7,707)\end{array}$ & $\begin{array}{l}\text { N14.1m } \\
(\$ 92,488)\end{array}$ & $\begin{array}{l}\text { Set by annual } \\
\text { collective } \\
\text { bargaining deal }\end{array}$ & - & - \\
\hline France & $\begin{array}{l}11.02 \mathrm{~m} \\
(\$ 6,756)\end{array}$ & $\begin{array}{l}12.3 \mathrm{~m} \\
(\$ 81,951)\end{array}$ & $\begin{array}{l}\$ 275,433 \\
(\$ 1,805)\end{array}$ & $\begin{array}{l}\$ 3.3 \mathrm{~m} \\
(\$ 21,664)\end{array}$ & $26.73 \%$ \\
\hline & $\begin{array}{l}\mathrm{N} 2.2 \mathrm{~m} \\
(\$ 14,53)\end{array}$ & $\begin{array}{l}\$ 26.7 \mathrm{~m} \\
(\$ 175,000)\end{array}$ & $\begin{array}{l}10,534 \\
(\$ 69,17) \\
\end{array}$ & $\begin{array}{l}\text { N126,413 } \\
(\$ 830)\end{array}$ & $0.47 \%$ \\
\hline
\end{tabular}

Source: Charles Udosen et al (2009:43).

The issue is whether enhanced labour productivity, assuming it is achievable with the numerous constraints imposed on labour is enough to bring about national development. National development is an all-encompassing, people-centred process hinged on government policies and programmes which are focused on bringing about 
increased quality of life for the citizenry. It manifests in the free exercise of democratic rights in state and the work place, high-level capital accumulation, a high level of industrialization and technological development with accentuation on manufacturing, instead of the dominance of agriculture and undue reliance on export of primary commodities as foreign exchange earner, or even reliance on a single commodity export for foreign exchange. In addition, in a developed economy not only is the salary and wage system humane, but also the process of growth is controlled by the indigenous people such that the needs of the citizens, both material and social services are affordably available. In effect, policies and actions must not only be directed towards serving the needs of the citizenry, they must also be driven and owned by them in a secure environment which guarantees the basic needs of food, shelter, water, electricity, health, and security of life and property (Akpotor 2014: 3-15). Where official corruption is accepted as a way of life, unstable power supply is the hallmark of the power sector, and a low level of infrastructural development, capped with crippling insecurity, of course, national development can only be wishful thinking. Certainly, it is the duty of the government to make this possible, failing which the process of its privatization can be set in motion.

The Nigerian government, throughout the period covered by this study paid lip service to its historic responsibility to Nigerians. It had embraced state-driven development at independence, thereby resolving the political economy issue raised earlier on the side of government shouldering the responsibility for providing the wants of the people. Government had sought to discharge this responsibility by means of National Development Plans, 1962-68, 1970-74, 1975-79, and 1980-85. Okigbo(1983) is of the view, however, that Nigeria's first national development plan was national only in name. It was not designed to promote interdependence and achieve a truly national economy, and instead, negated the national utilization of resources. It also emphasized only public sector expenditures, and ignored the contributions of the private sector to capital formation. The political leaderships were so ethno -regionally oriented that they plunged the country into a series of crises, including military rule, culminating in a 30-month civil war which ended in January, 1970 .Between 1970 and 1980, the military published the second and third national development plans, with lofty ideals of increasing the standard of living of Nigerians, making Nigeria a land of equal opportunities, and a developed country. Yet, the last three years of the military preparatory to their return of power to civilians were characterized by complete and total breakdown of discipline. As a consequence, the military left behind a restless and disorderly society, an ill-governed country which was littered with abandoned projects and "in which corruption had particularly become a way of life" (61-86). The fourth national development plan which the military prepared for the in coming civilian regime was not a plan, but a mere outline. Thus the first quarter century of Nigeria's independence was characterized by indiscipline in high places, including the emergence of corruption on a large scale, which robbed Nigerians of the resources and capacity to develop a self reliant economy.

National development plans were abandoned completely thereafter, in place of rolling plans, 1990-1999, years of renewed military rule, given that by 1986 "the development planning in Nigeria had hit the rock"(Ikeanyibe 2009: 202). At the end of the decade of the uncoordinated rolling plan during which unbridled corruption in all spheres reigned supreme, Nigerians became poorer, no thanks to the Structural Adjustment Programme (SAP) and political crisis created by Babangida's failed transition programme. The civilian regimes that ruled from 1999 to 2014, focused on private sector-led, market-oriented economy, the fact sheet of which has already been interrogated in the preceding sections of this essay. The study thus bears out the observation of Aboyade(1976) that performance would be limited and underdevelopment persist in a situation where control over available resources "is not motivated by the objectives of development", even as "Plans are drawn that make little impact on the pace and direction of development" $(16,29)$.

\section{Conclusion}

The Nigerian state, between 1990 and 2014, failed in its basic responsibilities to Nigerians, who in spite of their country's huge human and natural resources were made to live in penury, below the poverty line. The basic infrastructure and enabling environment, including the security of life and property needed for labour productivity and national development to flourish could not be guaranteed. Instead, the political class was obsessed with feathering its own nest at the expense of the work force. In the midst of a festering corruption which became a bye word for Nigeria, the famished working class was expected to increase its productivity by maximizing profit with few or no tools, while a private sector which was deliberately emasculated to serve as the lubricant of the client-patron machinery by which the political class rewarded its loyalists and marginalized its opponents was expected to serve as the engine of growth and national productivity. The consequence was that Nigeria remained an embarrassing paradox of want in the midst of plenty. In the circumstance, government's attempts to beam the search light on the labour force in its quest for explanation for and solution to Nigeria's low labour, and national development performance was misplaced. 


\section{Note}

*This is a revised version of a paper delivered at an interactive session organized as part of the local study tour of Delta State by Participants in the Senior Executive Course Sec No. 36, 2014, of the National Institute for Policy and Strategic Studies, (NIPSS), Kuru held at the Unity Hall, Government House, Asaba, Delta State, Nigeria, 2 May 2014.

\section{References}

Aboyade, O. (1976). Issues in the Development of Tropical Africa. Ibadan: Ibadan University Press.

Adewunmi, Funmi. (2014). Industrial Relations, Trade Unionism and Collective Bargaining, in ASUU National Secretariat, Meeting the Challenges of Effective Leadership in the Nigeria University System: Leadership Training Manual 2014(pp31-40) Abuja: Academic Staff Union of Universities.

African Economic Outlook, 2014, Nigeria, 2-14 Available at www.africaneconomicoutlook.org , (accessed 10 April 2014).

Akanni, Olomola P, (2007). Oil Wealth and Economic Growth in Oil Exporting, African Countries. AERC Research Paper, 170.Nairobi: African Economic Consortium.

Ake, Claude. (ed.) (1996). Democracy and Development in Africa. Ibadan: Spectrum Books.

Akpotor, Sunday A. (2014). Struggling for the Minds of Men: Foreign Policy, Economic Development, The Compare, 36, in the Series of Inaugural Lectures, Delta State University, Abraka-Nigeria, 19 June. Abraka: Delta State University.

Aluko, M. E.( 2005). Nigeria and her Membership of OPEC. Available at http://AfricaEconomicAnalysis.org (Accessed on 19 May, 2014).

Amali, Ebele. (2011). Nigeria's Political Economy: Post-Colonial Development Analysis, in Michael O. Maduagwu ;Aja Akpuru-Aja; Ibrahim M. Jumare, and Oluwafunmilayo J. Para-Mallam ( eds.),Nigeria's 50 Years of Nation-Building: Stock-Taking and Looking Ahead (pp.391-406). Kuru-Nigeria: National Institute for Policy and Strategic Studies.

Ark, Bart V. and McGuckin, Robert H. ( 1999). International Comparisons of Labour Productivity and Per Capita Income. Monthly Labour Review, July: 33-41.

Awe A. A. and Ayeni R. K., (2010). "Empirical Investigation into Industrial Relations and National Productivity in Nigeria", in: Ozean Journal of Applied Sciences vol. 3, No.3, pp. 336.

Babawale, Tunde.(ed.) (2003). Urban Violence, Ethnic Militias and the Challenge of Democratic Consolidation in Nigeria. Lagos: Malthouse Press.

Caporaso, A. J. and Levine, D. P. (2005). Theories of Political Economy, 13th Printing. Cambridge University Press

Chete, L. N., J.O. Adeoti., F. M. Adeyinka and O. Ogundele. (ed.) (2014). Industrial Development and Growth in Nigeria: Lessons and Challenges. Finland: UMI-WIDER.

Diamond, L; Kirk-Greene A., and Oyechian. O. (1997). Introduction: The Politics of Transition without End, in Larry Diamond, A. Kirk-Greene, and Oyeleye Oyediran (eds.), Transition without End: Nigerian Politics and Civil Societies under Babangida( pp. xv-lx). Ibadan: Vantage Publisher.

Dudley, Billy J. (ed.) (1982). An Introduction to Nigerian Government and Politics. London: The Macmillan Press.

Earnings of Nigerian Legislators Compared to other countries by Punch. Transparency Nigeria, 16 December 2010. Online. Available at http://www.transparencyng.com/index.php?op (Accessed April 20, 2014).

Fashina, Oladipo. (2014). History and Development of Trade Unionism in Nigeria: A Political Economy 
Approach, in ASUU National Secretariat, Meeting the Challenges of Effective Leadership in the Nigeria University System: Leadership Training Manual 2014 (pp5-19). Abuja: Academic Staff Union of Universities.

Folarin, S. (2014). We have nothing to hide, says LASG. Punch 29 April. http://www.punchng.com/news/wehave-nothing-to-hide. Accessed 4/6/14.

Fashola Restates Case for Non-Central Wage Policy as NIPSS Sermon Executive Course 36 members visit. The Gazette News. http://www.thegazettenews.com/2014/01/28/fashola-restates-case. (Acessed 4/6/14).

Hassan, Muritala B (2014). Boko Haram Insurgency and the Spate of Insecurity in Nigeria: Manifestation of Governance Crisis, in: Research on Humanities and Social Science , vol.4, No.18, pp. 9-18.

Harsch, Ernest. (1993). Accumulator and Democrats: Challenge State Corruption in Africa, in:The Journal of Modern African Studies, vol.31, No.1, pp. 31-48.

Ikeanyibe, O. M. (2009). Development Planning in Nigeria: Reflections on the National Economic Empowerment and Development Strategy (NEEDS) 2003-2007, in: Journal of Social Science, vol. 20, No. 3, pp. $197-210$.

Imhonopi, David and Urim, Ugochukwu M. (2012). Nigeria's Expensive Democracy: A Confederal Option for Development. In: Journal of Sustainable Development in Africa, vol.14, No.7, pp. 70-80.

Law, Robin. (1978). The Marxist Approach to Historical Explanation: Tarikh 6, ( 1), 40-50.

Labour Unions Begin Protest Against Senate Bill to Decentralize Minimum Wage for Nigerian Workers. Osun Defender http://www.osundefender.org/?p=122023 . ( Accessed

4/06/14)

Mordi, E.N. (2014). Delta State: The Challenge of Development: Text of a Lecture Delivered to Participants of the Youth Empowerment Training Programme Organized by the Delta State Government Under the Auspices of the Ministry of Higher Education, Asaba, Held at Songhai Delta, Amukpe Sapele. 13 June.

Mordi, E.N. (2009). The Millennium Development Goals and the Challenge of Sustainable Development in Africa: A Historical Discourse; In Christian Ewhrudjakpor and Atare Andy Otite, eds. Millennium Development Goals and Challenges: Issues on Education and Poverty (pp123-136). Abraka,: Faculty of the Social Sciences, Delta State University

Mordi, E.N. (2004). The Return of Democracy and Escalating Violence in Nigeria 1999-2004: A Historical Analysis, in Christopher O. Orubu, Emmanuel N. Mordi and A. Oritsegbemi Ifediora (eds.), Nigeria: The Challenge of Democracy and Development in the Twenty-First Century,(pp159-76). Benin City: Ethiope Publishing.

Mwakilishi (2014). A \$510 Billion GDP, Nigeria Overtakes South Africa as Africa's Biggest Economy: Mwakilishi.com.newsletter. 7 April. (Accessed 2/6/14).

Nwanegbo Jaja, C and Odigbo Jude, (2013). Security and National Development in Nigeria: The Threat of Boko Haram. In: International Journal of Humanistic and Social Science, vol.3, No.4, pp. 285-291.

Ogbeidi, M. M. (2012). Political Leadership and Corruption in Nigeria Since 1960: A Socio-Economic Analysis, in: Journal of Nigeria Studies, vol.1, No.2, pp. 1-25.

Ogbonna, G.N.P Appa Ebimobowei. (2012). Petroleum Income and Nigerian Economy: Empirical Evidence, In: Arabian Journal of Business and Management Review (OMAN Chapter) vol.1, No.9, pp. 33-39 April.

Okaka Emmanuel O. and Eriaguna, Edio (2011). Government Agents in Nigeria's Industrial Relations System: JORIND, (9)1: June. 187-192. Available at http://www.transcampus.org/journals.www.ajol.info/journals/jorind. ( Accessed in April 24, 2014).

Okedinachi, P. (2014). Organised Labour Rejects Confab's Plan to Decentralize Union. May 11. World stage Newsonline http://www.worldstagegrop.com/index.php?active accessed June 4, 2014. 
Okigbo, P.N.C. (1983). Economic Planning in Nigeria since 1960: in Proceedings of the National Conference on Nigeria since Independence. Zaria, March, 1983. Vol. II: the Economic and Social Development of Nigeria (eds.), Kayode, M.O. \& Usman, Y. B. pp. 57-89.

$\begin{array}{llll}\text { OPEC Statistical } & \text { Bulletin } & \text { Available }\end{array}$ http://www.opec.org/opec_web/static_files_project/media/downloads/publications/ASB2013.pdf

(Accessed 27 April 2014).

Osaghae, Eghosa E. (2008). Separatist Agitations in Nigeria, 1980-1986, in Dele Layiwola, Olawale Albert and Bernard Muller (eds.), The Contents of Non-Linear History (pp233-62). Ibadan: Sefer Books.

Rotberg, Robert I. (2004). Failed States, Collapsed States, Weak States: Causes and Indicators, in Robert I. Rotberg (ed.), When States Fail: Causes and Consequences (pp 2-25). Princeton, New Jersey: Princeton University Press.

Tamuno, Tekena (1970) Separatist Agitations in Nigeria Since 1914, in: Journal of Modern African Studies vol. 8, No.4, pp. 563-84.

Transparency International, Corruption Perceptions Index (2013). Available at http://www.transparency.org Accessed at 8/10/2014

Transparency International. (2006). Global Corruption Report 2005. London: Pluto Press Available at http://www.transparency.org/whatwedo/pub/global-corruption-report-2006_coruption-andhealth . Accessed 11 April 2014.

Udosen, Charles, Etok, Abasi-Ifreke S; and George, I.N. (2009). Fifty Years of Oil Exploration in Nigeria: The Paradox of Plenty, in: Global Journal of Social Sciences, vol. 8, No.2, pp. 37-47.

United States Embassy in Nigeria (2012, April). Nigeria Economic Fact Sheet online.http://www.photos.state.gov/libraries/nigeria/231771/public/december-economicfactssheet.pdf . 
The IISTE is a pioneer in the Open-Access hosting service and academic event management. The aim of the firm is Accelerating Global Knowledge Sharing.

More information about the firm can be found on the homepage:

http://www.iiste.org

\section{CALL FOR JOURNAL PAPERS}

There are more than 30 peer-reviewed academic journals hosted under the hosting platform.

Prospective authors of journals can find the submission instruction on the following page: http://www.iiste.org/journals/ All the journals articles are available online to the readers all over the world without financial, legal, or technical barriers other than those inseparable from gaining access to the internet itself. Paper version of the journals is also available upon request of readers and authors.

\section{MORE RESOURCES}

Book publication information: http://www.iiste.org/book/

Academic conference: http://www.iiste.org/conference/upcoming-conferences-call-for-paper/

\section{IISTE Knowledge Sharing Partners}

EBSCO, Index Copernicus, Ulrich's Periodicals Directory, JournalTOCS, PKP Open Archives Harvester, Bielefeld Academic Search Engine, Elektronische Zeitschriftenbibliothek EZB, Open J-Gate, OCLC WorldCat, Universe Digtial Library, NewJour, Google Scholar

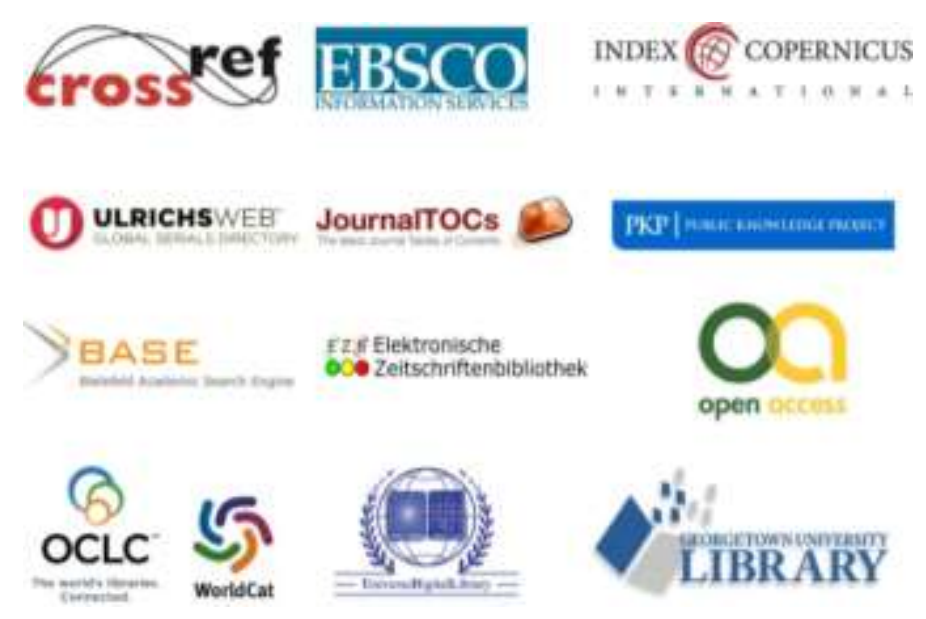

